\title{
Synthesis of Sequential Polyamide by Direct Polycondensation
}

\author{
Mitsuru Ueda, Mayumi Kakuta, Tatsuya Morosumi, and Rikiya Sato \\ Department of Polymer Chemistry, Faculty of Engineering, Yamagata University, \\ Yonezawa, Yamagata 992, Japan
}

(Received August 27, 1990)

\begin{abstract}
A convenient method for the synthesis of sequential polyamide (head-to-head, or tail-to-tail) has been developed. This polymer was prepared by the direct polycondensation of symmetric monomer (YccY), isophthalic acid (2b) with nonsymmetric monomer (XabX), 2,6dimethyl-p-phenylenediamine (4) using the activating agent, diphenyl(2,3-dihydro-2-thioxo-3benzoxazolyl)phosphate (1). The polycondensation was carried out by slow addition of $\mathbf{2 b}$ to $\mathbf{4}$, and gave the sequential (head-to-head, or tail-to-tail) polyamide (14) with inherent viscosity of $0.2 \mathrm{dlg}^{-1}$. The authentic polyamides with different values of $\mathrm{s}$ (probability of -accb-placement) were prepared to verify the structure of polyamide 14. Furthermore, the model reaction was studied in detail to demonstrate the feasibility of the sequential polyamidation.

KEY WORDS Sequential Polyamide / Direct Polycondensation / Activating

Agent / Nonsymmetric Diamine / Dicarboxylic Acid /
\end{abstract}

A direct polycondensation using activating agents had been initiated to realize for the in situ activation of carboxylic acids, followed by condensation under mild conditions. Now, this method has been developed as a useful method for the synthesis of polyamides, polyesters, and other condensation polymers, where organophosphorus reagents have been found useful for the activation of carboxylic acids. ${ }^{1}$

In the preceding paper, ${ }^{2}$ we reported a convenient method for the synthesis of polyamides containing hydroxyl, amino, and carboxyl substituents on the aromatic rings of the polymer backbones. These polymers were prepared readily by the chemoselective polyamidation of dicarboxylic acids with diamines containing various functional groups using the activating agent diphenyl(2,3-dihydro-2thioxo-3-benzoxazolyl)phosphate (1).

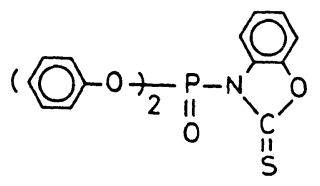

The next target is to established the method on the synthesis of sequential polyamides using the activating agents. The synthesis of proteins in the living cells from activated amino acids takes places on the surface of ribosomes. The resulting polypeptide molecules have a specific amino acid sequence governed by the m-RNA that was coded by the DNA in the nucleus of the cell. On the other hand, we don't have the such active templates that directs the sequence of alignment of amino acids. Therefore, the chemical synthesis of polypeptides is carried out step by step with the addition of each amino acid residue.

Most of condensation polymers are prepared by the reactions between two different bifunctional symmetric monomers. However, the synthesis of condensation polymers from a symmetric (YccY) and a nonsymmetric (XabX) monomer is still a little investigated area. Pino, Suter et al $^{3-10}$ have been reported a series of studies of the influence of constitutional isomerism on the physical properties of polycondensates, where theoretical aspects of structural regularity of polycondensation were 

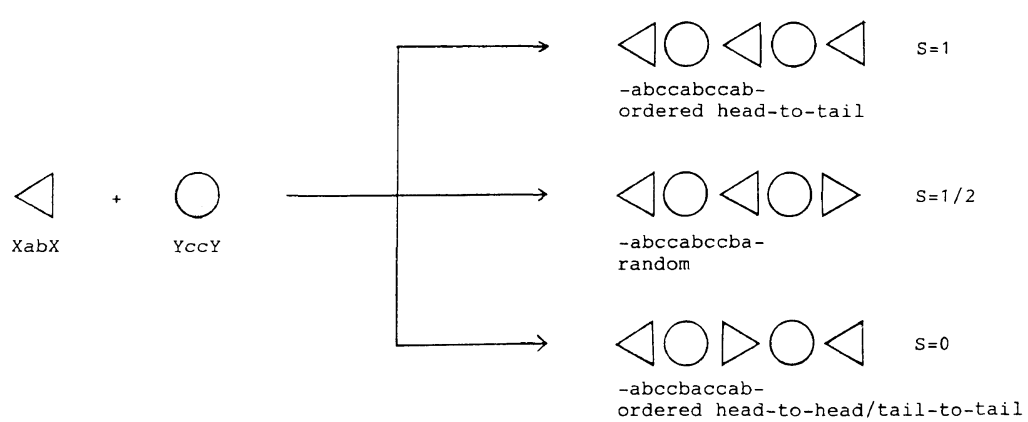

Figure 1. Schematic representation of polymers with different values of $s$.

systematically investigated. They showed the probability of two adjacent nonsymmetric units in a chain to point in the same directions, $s$, is used to quantify structural regularity. When $\mathrm{XabX}$ is reacted with YccY, the shortest structure elements in the polymer are -acca-, -accb-, -bcca-, and -bccb-, where the two structure, -accb- and -bcca- will be indistinguishable. The probability $s$ of an -accbplacement is given by

$$
s=[\mathrm{accb}] /([\mathrm{acca}]+[\mathrm{accb}]+[\mathrm{bccb}])
$$

where $[\mathrm{accb}]$ includes $-\mathrm{accb}-$ as well as - bccaarrangements.

Three general cases are shown in Figure 1. For a chain where all units point in the same direction $s=1$ (head-to-tail); when the orientation of the units is strictly alternating $s=0$ (head-to-head or tail-to-tail). If no preference for the different enhancement exists $s=1 / 2$ (random chain).

Based on the detailed kinetic consideration, the following conclusion was deduced. A difference in the reactivity of functional groups in an nonsymmetric monomer is not sufficient to produce condensation polymers with a sequential structure. If -aX group of the nonsymmetric monomer is more reactive than -bX group, immediate mixing of two monomers gives a random polymer. If the symmetric monomer (YccY) is fed very slowly to the reaction mixture containing all of the nonsymmetric monomer (XabX), the highest possible head-to-head or tail-to-tail regularity is achiev- ed.

We now report a successful synthesis of sequential (head-to-head or tail-to-tail) polyamide by the direct polycondensation is isophthalic acid with 2,6-dimethyl-p-phenylenediamine using the activating agent (1).

\section{EXPERIMENTAL}

\section{Materials}

$\mathrm{N}$-Methyl-2-pyrrolidone (NMP) was purified by vacuum distillation and stored over 4- $\AA$ molecular sieves. Benzoic acid (2a) and isophthalic acid (2b) was purified by recrystallization. Triethylamine (TEA) was purified by the usual method. Other reagents and solvents were obtained commercially and used as received.

The activating agent diphenyl(2,3-dihydro2-thioxo-3-benzoxazolyl)phosphate (1) was prepared according to the reported procedure. ${ }^{11}$

2,6-Dimethyl-p-phenylenediamine (4). This compound was prepared by the coupling reaction of diazonium salts of $m$-aminobenzenesulfonic acid with 2,6-dimethylaniline (3), followed by reduction with sodium hydrosulfite. ${ }^{12}$ Recrystallization from $n$-hexane gave faint pink plates. $\mathrm{mp} 103-105^{\circ} \mathrm{C}$ (lit. $^{12}$ $\left.103-104^{\circ} \mathrm{C}\right)$. IR (KBr) $v 3360,3380 \mathrm{~cm}^{-1}$ (N-H).

\section{Kinetic Measurement}

Equimolar amounts of benzoic acid and 
substituted aniline was reacted in the presence of 1 , in NMP at $25^{\circ} \mathrm{C}$ for a specified time. Rates of the aminolysis reaction were followed by measuring the weights of the isolated products. The overall second order rate constants were calculated from the slopes of the reciprocal plots of $(a-x)$ versus time $(t)$ following the rate equation $1 /(a-x)-1 / a=k t$, where $a$ and $x$ are the initial concentration of benzoic acid and the concentration of product at any time.

$N, N^{\prime}$-Dibenzoyl-2,6-dimethyl-p-phenylenediamine (5). The activating agent $1(0.843 \mathrm{~g}, 2.2$ mmol) was added to a solution of $2 \mathrm{a}(0.244 \mathrm{~g}$, $2 \mathrm{mmol}), 4(0.136 \mathrm{~g}, 1 \mathrm{mmol})$ and TEA $(0.28 \mathrm{ml}$, $2 \mathrm{mmol})$ in NMP $(1 \mathrm{ml})$ at room temperature. The mixture was stirred until 1 was dissolved completely in NMP, and then at $70^{\circ} \mathrm{C}$ for $24 \mathrm{~h}$. The solution was poured into $10 \%$ aqueous sodium hydrogen carbonate. The precipitate was filtered, washed with water, and dried. The yield was $0.344 \mathrm{~g}(99 \%)$. Recrystallization from methanol afforded white crystals. mp $289^{\circ} \mathrm{C}$ (by DTA). IR (KBr) $v 3240(\mathrm{~N}-\mathrm{H}), 1640 \mathrm{~cm}^{-1}$ $(\mathrm{C}=\mathrm{O}) .{ }^{13} \mathrm{C} \mathrm{NMR}\left(\mathrm{CF}_{3} \mathrm{COOD}\right): 171.4,172.7$ $(\mathrm{C}=\mathrm{O}), \quad 18.8 \quad\left(\mathrm{CH}_{3}\right), \quad 139.9, \quad 138.4,135.9$, 135.0, 133.9, 133.8, 132.8, 132.2, 131.9, 129.1, $124.2,124.0 \mathrm{ppm}\left(\mathrm{C}_{\text {arom }}\right)$. Anal. Calcd for $\mathrm{C}_{22} \mathrm{H}_{20} \mathrm{~N}_{2} \mathrm{O}_{2}$ : C, $76.72 \% ; \mathrm{H}, 5.85 \% ; \mathrm{N}$, $8.13 \%$. Found: C, $76.40 \%$; H, $5.81 \%$; N, $8.00 \%$.

$N, N^{\prime}$-Di(2', $6^{\prime}$-dimethylphenyl)isophthalamide (6). To a solution of $\mathbf{2 b}(0.0831 \mathrm{~g}, 0.5 \mathrm{mmol})$, $3(0.12 \mathrm{ml}, 1 \mathrm{mmol})$, and TEA $(0.14 \mathrm{ml}$, $1 \mathrm{mmol})$ in NMP $(1 \mathrm{ml})$ was added the activating agent $1(0.421 \mathrm{~g}, 1.1 \mathrm{mmol})$. The mixture was stirred until 1 was dissolved completely in NMP, and then at $100^{\circ} \mathrm{C}$ for $24 \mathrm{~h}$. The product was isolated as described above. The yield was $0.176 \mathrm{~g}(95 \%)$. Recrystallization from methanol yielded white crystals, $\mathrm{mp}$ $293^{\circ} \mathrm{C}$ (by DTA). IR (KBr) $v 3200(\mathrm{~N}-\mathrm{H})$, $1640 \mathrm{~cm}^{-1}(\mathrm{C}=\mathrm{O}) .{ }^{13} \mathrm{C} \mathrm{NMR}\left(\mathrm{CF}_{3} \mathrm{COOD}\right)$ : $172.8(\mathrm{C}=\mathrm{O}), 18.5\left(\mathrm{CH}_{3}\right), 137.8,135.1,135.0$, $134.9,133.9,131.4,133.1,130.6 \mathrm{ppm}\left(\mathrm{C}_{\text {arom }}\right)$. Anal. Calcd for $\mathrm{C}_{24} \mathrm{H}_{24} \mathrm{~N}_{2} \mathrm{O}_{2}: \mathrm{C}, 77.39 \% ; \mathrm{H}$, $6.49 \%$;, $7.52 \%$. Found: C, $77.28 \% ; \mathrm{H}$,
$6.41 \% ; \mathrm{N}, 7.47 \%$.

$N, N^{\prime}$-Di(3', $5^{\prime}$-dimethylphenyl)isophthalamide

(7) The activating agent $1(0.422 \mathrm{~g}, 1.1 \mathrm{mmol})$ was added to a solution of $\mathbf{2 b}(0.0831 \mathrm{~g}, 0.5$ $\mathrm{mmol}), 3,5$-dimethylaniline $(0.12 \mathrm{ml}, 1.0 \mathrm{mmol})$, and TEA $(0.14 \mathrm{ml}, 1.0 \mathrm{mmol})$ in NMP $(1 \mathrm{ml})$. The mixture was stirred at room temperature for $1 \mathrm{~h}$. The product was isolated as described above. The yield was $0.174 \mathrm{~g}(94 \%)$. Recrystalization from methanol gave white needles. $\mathrm{mp} 286^{\circ} \mathrm{C}$ (by DTA). IR (KBr) $v 3230$ $(\mathrm{N}-\mathrm{H}), \quad 1640 \mathrm{~cm}^{-1} \quad(\mathrm{C}=\mathrm{O}) . \quad{ }^{13} \mathrm{C} \quad \mathrm{NMR}$ $\left(\mathrm{CF}_{3} \mathrm{COOD}\right)$ : $171.7(\mathrm{C}=\mathrm{O}), 21.4\left(\mathrm{CH}_{3}\right), 141.7$, 136.1 135.3, 133.6, 131.8, 128.8, 122.8, 122.3 ppm $\left(\mathrm{C}_{\text {arom }}\right)$. Anal. Calcd for $\mathrm{C}_{24} \mathrm{H}_{24} \mathrm{~N}_{2} \mathrm{O}_{2}: \mathrm{C}$, $77.39 \% ; \mathrm{H}, 6.49 \%$; N, 7.52\%. Found: C, $77.39 \%$; H, $6.46 \%$; N, $7.43 \%$.

\section{Authentic Polyamide (9)}

$N, N^{\prime}$-Di(4'-amino-3', $5^{\prime}$-dimethylphenyl)isophthalamide $(\boldsymbol{8})$. A solution of $1(0.843 \mathrm{~g}$, $2.2 \mathrm{mmol}), 2 \mathrm{~b}(0.166 \mathrm{~g}, 1 \mathrm{mmol})$, and TEA $(0.28 \mathrm{ml}, 2 \mathrm{mmol})$ in NMP $(1 \mathrm{ml})$ was added dropwise at room temperature with stirring to a solution of $4(0.272 \mathrm{~g}, 2 \mathrm{mmol})$ in NMP $(1 \mathrm{ml})$. The addition was completed in $30 \mathrm{~min}$, and stirring was continued for an additional $1 \mathrm{~h}$. The solution was poured into $10 \%$ aqueous sodium hydrogen carbonate $(100 \mathrm{ml})$. A precipitate formed, and it was collected by filtration, washed with water, and dried in vacuo. The yield was $0.395 \mathrm{~g}$ (98\%). Recrystallization from THF-water produced a faint purple powder. $\mathrm{mp} 287^{\circ} \mathrm{C}$ (by DTA). IR (KBr) $v 3400$, $3260,3200 \mathrm{~cm}^{-1}(\mathrm{~N}-\mathrm{H}), 1620 \mathrm{~cm}^{-1}(\mathrm{C}=\mathrm{O}) .{ }^{13} \mathrm{C}$ NMR ( $\left.\mathrm{CF}_{3} \mathrm{COOD}\right): 175.0,173.9(\mathrm{C}=\mathrm{O}), 18.8$ $\left(\mathrm{CH}_{3}\right), 140.0,138.0,136.0,135.8,133.3,132.4$, $131.1,131.0,130.6,130.5,129.3,124.8 \mathrm{ppm}$ $\left(\mathrm{C}_{\text {arom }}\right)$. Anal. Calcd for $\mathrm{C}_{24} \mathrm{H}_{26} \mathrm{~N}_{4} \mathrm{O}_{2} \cdot 1 / 2$ $\mathrm{H}_{2} \mathrm{O}: \mathrm{C}, 70.05 \%$; H, 6.61\%; N, $13.61 \%$. Found: C, $69.95 \%$; H, 6.67\%; N, $13.41 \%$.

The activating agent $1(0.422 \mathrm{~g}, 1.1 \mathrm{mmol})$ was added to a solution of $8(0.206 \mathrm{~g}$, $0.5 \mathrm{mmol}), 2 \mathrm{~b}(0.0831 \mathrm{~g}, 0.5 \mathrm{mmol})$, and TEA $(0.14 \mathrm{ml}, 1 \mathrm{mmol})$ in NMP $(1 \mathrm{ml})$. The mixture was stirred until 1 was completely dissolved in 
NMP, and then at $100^{\circ} \mathrm{C}$ for $24 \mathrm{~h}$. The resulting solution was diluted with NMP and poured into methanol $(200 \mathrm{ml})$. The polymer that precipitated was filtered and was refluxed in methanol for $2 \mathrm{~h}$. The polymer was collected and dried in vacuo at $100^{\circ} \mathrm{C}$. The yield was $0.237 \mathrm{~g}(86 \%)$. The inherent viscosity of the polymer in NMP was $0.26 \mathrm{dlg}^{-1}$ at a concentration of $0.5 \mathrm{~g} \mathrm{dl}^{-1}$ at $30^{\circ} \mathrm{C}$. IR $(\mathrm{KBr})$ $v 3240(\mathrm{~N}-\mathrm{H}), 1640 \mathrm{~cm}^{-1}(\mathrm{C}=\mathrm{O})$. Anal. Calcd for $\mathrm{C}_{32} \mathrm{H}_{28} \mathrm{~N}_{4} \mathrm{O}_{4} \cdot \mathrm{H}_{2} \mathrm{O}: \mathrm{C}, 69.80 \% ; \mathrm{H}, 5.49 \%$, N, 10.18 . Found: C, $69.79 \% ; H, 5.25 \%$; N, $9.91 \%$.

\section{Authentic Polyamide (12)}

4'-Amino-3-methoxycarbonyl-3',5'-dimethylbenzanilide (10). The activating agent 1 was added to a solution of $4(0.272 \mathrm{~g}, 2 \mathrm{mmol})$, methyl hydrogen isophthalate $(0.360 \mathrm{~g}, 2$ mmol), and TEA $(0.28 \mathrm{ml}, 2 \mathrm{mmol})$ in NMP $(1.5 \mathrm{ml})$. The solution was stirred at room temperature for $2 \mathrm{~h}$, and poured into $10 \%$ aqueous sodium hydrogen carbonate. The precipitate was filtered, washed with water, and dried. The yield was $0.575 \mathrm{~g}(96 \%)$. Recrystallization from methanol-water yielded white crystals. mp $147-150^{\circ} \mathrm{C}$. IR $(\mathrm{KBr}) v$ $3320,3220 \mathrm{~cm}^{-1}(\mathrm{~N}-\mathrm{H}), 1720,1630 \mathrm{~cm}^{-1}$ $(\mathrm{C}=\mathrm{O})$. Anal. Calcd for $\mathrm{C}_{17} \mathrm{H}_{18} \mathrm{~N}_{2} \mathrm{O}_{3}$ : C, $68.44 \%$; H, 6.08\%; N, 9.39\%. Found: C, $68.30 \% ; \mathrm{H}, 6.13 \%$; N, 9.26\%.

4'-Amino-3-carboxy-3', 5'-dimethylbenzanilide (11). Compound $10(0.448 \mathrm{~g}, 1.5 \mathrm{mmol})$ was dissolved in ethanol $(15 \mathrm{ml})$. To this was added potassium hydroxide $(0.256 \mathrm{~g}, 4.5$ $\mathrm{mmol}$ ), and stirred at $80^{\circ} \mathrm{C}$ for $2 \mathrm{~h}$. The solvent was removed under reduced pressure, and the residue was dissolved in water. The solution was made to $\mathrm{pH} 4$ with $\mathrm{HCl}$. The precipitate was filtered, washed with water, and dried. The yield was $0.333 \mathrm{~g} \mathrm{(78 \% )}$. Recrystallization from methanol-water gave a faint yellow powder. $\mathrm{mp} 273-274^{\circ} \mathrm{C}$. IR $(\mathrm{KBr}) v 3240 \mathrm{~cm}^{-1}(\mathrm{~N}-\mathrm{H})$, $1680,1630 \mathrm{~cm}^{-1} \quad(\mathrm{C}=\mathrm{O})$. Anal. Calcd for $\mathrm{C}_{16} \mathrm{H}_{16} \mathrm{~N}_{2} \mathrm{O}_{3}$ : C, 67.60\%; $\mathrm{H}, 5.67 \% ; \mathrm{N}$, $9.85 \%$. Found: $67.75 \%$; H, $5.74 \%$; N, $9.81 \%$.
The activating agent $1(0.422 \mathrm{~g}, 1.1 \mathrm{mmol})$ was added to a solution of $11(0.284 \mathrm{~g}, 1 \mathrm{mmol})$, and TEA $(0.14 \mathrm{ml}, 1 \mathrm{mmol})$ in NMP $(1 \mathrm{ml})$. The mixture was stirred until 1 was completely dissolved in NMP, and then at $100^{\circ} \mathrm{C}$ for $24 \mathrm{~h}$. The polymer was isolated as described in the synthesis of 9. The yield was $0.260 \mathrm{~g}(94 \%)$. The inherent viscosity of the polymer in NMP was $0.37 \mathrm{dl} \mathrm{g}^{-1}$ at a concentration of $0.5 \mathrm{~g} \mathrm{dl}^{-1}$ at $30^{\circ} \mathrm{C}$. IR $(\mathrm{KBr}) \vee 3240(\mathrm{~N}-\mathrm{H}), 1640 \mathrm{~cm}^{-1}$ $(\mathrm{C}=\mathrm{O}) .{ }^{13} \mathrm{C}$ NMR $\left(\mathrm{CF}_{3} \mathrm{COOD}\right): 171.4,172.9$ $(\mathrm{C}=\mathrm{O}), 18.8\left(\mathrm{CH}_{3}\right), 139.9,138.3,134.8,133.8$, $133.7,132.3,132.0,129.1,124.4 \mathrm{ppm}\left(\mathrm{C}_{\text {arom }}\right)$. Anal. Calcd for $\mathrm{C}_{16} \mathrm{H}_{14} \mathrm{~N}_{2} \mathrm{O}_{2} \cdot 2 / 3 \mathrm{H}_{2} \mathrm{O}: \mathrm{C}$, $69.05 \%$; H, $5.55 \%$; N, $10.06 \%$. Found: C, $69.29 \%$; H, 5.28\%; N, 9.55\%.

Polyamide (13) from Isophthaloyl Chloride and 4 . The solution of $4(0.136 \mathrm{~g}, 1 \mathrm{mmol})$ in NMP (1 ml) was cooled to a mush with a dry ice-acetone bath. To this was added a solution of isophthaloyl chloride $(0.203 \mathrm{~g}, 1 \mathrm{mmol})$ in NMP ( $1 \mathrm{ml}$ ) in one portion, and the cooling bath was changed to an ice-water bath. The mixture was stirred for $30 \mathrm{~min}$ at $0^{\circ} \mathrm{C}$ or below and for additional $18 \mathrm{~h}$ at room temperature. The polymer was isolated as described above. A $93 \%$ yield of the polymer having an inherent viscosity of $0.18 \mathrm{dl} \mathrm{g}^{-1}$ in NMP $\left(\mathrm{C}=0.5 \mathrm{~g} \mathrm{dl}^{-1}\right.$ at $\left.30^{\circ} \mathrm{C}\right)$ was obtained. IR $(\mathrm{KBr}) v 3250 \mathrm{~cm}^{-1}$ $(\mathrm{N}-\mathrm{H}), \quad 1640 \mathrm{~cm}^{-1} \quad(\mathrm{C}=\mathrm{O}) . \quad{ }^{13} \mathrm{C} \quad \mathrm{NMR}$ ( $\left.\mathrm{CF}_{3} \mathrm{COOD}\right):$ 172.7, 172.5, $171.2(\mathrm{C}=\mathrm{O}), 18.7$ $\left(\mathrm{CH}_{3}\right), 139.7,138.2,136.0,135.7,134.9,134.7$, 134.0, 133.9, 133.7, 133.6, 133.5, 132.1, 131.9, $131.8,129.0,128.9,124.2,123.9 \mathrm{ppm}\left(\mathrm{C}_{\text {arom }}\right)$.

Polyamide (14) from $2 \boldsymbol{b}$ and 4 . To a solution of $4(0.136 \mathrm{~g}, 1 \mathrm{mmol})$ in NMP $(0.5 \mathrm{ml})$ was added dropwise at room temperature a solution of $2 \mathrm{~b}(0.166 \mathrm{~g}, 1 \mathrm{mmol}), 1(0.843 \mathrm{~g}$, $2.2 \mathrm{mmol})$, and TEA $(0.28 \mathrm{ml}, 2 \mathrm{mmol})$ in NMP $(1 \mathrm{ml})$. The addition was completed in $30 \mathrm{~min}$, and stirring was continued for an additional $1 \mathrm{~h}$. The polymer was isolated as described above. The yield was $0.249 \mathrm{~g}(94 \%)$. The inherent viscosity was $0.2 \mathrm{dlg}^{-1}$ in NMP $\left(\mathrm{C}=0.5 \mathrm{~g} \mathrm{dl}^{-1}\right.$ at $\left.30^{\circ} \mathrm{C}\right)$. IR (KBr): $v 3240 \mathrm{~cm}^{-1}$ $(\mathrm{N}-\mathrm{H}), 1630 \mathrm{~cm}^{-1}(\mathrm{C}=\mathrm{O})$. Anal. Calcd for 
$\mathrm{C}_{32} \mathrm{H}_{28} \mathrm{~N}_{4} \mathrm{O}_{4} \cdot 6 / 5 \mathrm{H}_{2} \mathrm{O}: \mathrm{C}, 69.35 \% ; \mathrm{H}, 5.52 \%$; N, $10.11 \%$. Found: C, $69.20 \%$; H, 5.29\%; N, $9.91 \%$.

3',5'-Dimethyl-3-methoxycarbonylbenzanilide (15). The activating agent $1(0.805 \mathrm{~g}, 2.1$ mmol) was added to a solution of methyl hydrogen isophthalate $(0.360 \mathrm{~g}, 2.0 \mathrm{mmol})$, 3,5-dimethylaniline $(0.24 \mathrm{ml}, 2 \mathrm{mmol})$, and TEA $(0.28 \mathrm{ml}, 2.0 \mathrm{mmol})$ in NMP $(1.5 \mathrm{ml})$ at room temperature. The mixture was stirred for $2 \mathrm{~h}$ at this temperature. The product was isolated as described in the sythesis of model compounds. The yield was $0.474 \mathrm{~g}(84 \%)$. Recrystallization from methanol-water gave white plates. $\mathrm{mp} 117-119^{\circ} \mathrm{C}$. IR $(\mathrm{KBr})$ v 3390 $(\mathrm{N}-\mathrm{H}), 1720,1660 \mathrm{~cm}^{-1}(\mathrm{C}=\mathrm{O})$. Anal. Calcd for $\mathrm{C}_{17} \mathrm{H}_{17} \mathrm{NO}_{3}$ : C, $72.07 \% ; \mathrm{H}, 6.05 \% ; \mathrm{N}$, $4.94 \%$. Found: C, $72.02 \% ; \mathrm{H}, 6.03 \% ; \mathrm{N}$, $4.80 \%$.

3-Carboxy-3',5'-dimethylbenzanilide (16). Compound $15(0.425 \mathrm{~g}, 1.5 \mathrm{mmol})$ was dissolved in ethanol $(15 \mathrm{ml})$. To this was added potassium hydroxide $(0.168 \mathrm{~g}, 3 \mathrm{mmol})$, and stirred at $80^{\circ} \mathrm{C}$ for $2 \mathrm{~h}$. The solution was concentrated, and the residue was diluted with water. Acidification of the solution with $\mathrm{HCl}$ gave precipitate, which was filtered, washed with water, and dried. The yield was $0.385 \mathrm{~g}$ (95\%). Recrystallization from methanol-water yielded white needles. $\mathrm{mp} 262-265^{\circ} \mathrm{C}$. IR (KBr) v $3290(\mathrm{~N}-\mathrm{H}), 1700,1650 \mathrm{~cm}^{-1}(\mathrm{C}=\mathrm{O})$. Anal. Calcd for $\mathrm{C}_{16} \mathrm{H}_{15} \mathrm{NO}_{3}: \mathrm{C}, 71.36 \% ; \mathrm{H}$, $5.51 \%$; N, 5.20\%. Found: C, 71.66\%; H, $5.66 \% ; \mathrm{N}, 5.15 \%$.

$N-\left(2^{\prime}, 6^{\prime}\right.$-dimethylphenyl $)-N^{\prime}-\left(3^{\prime}, 5^{\prime}\right.$-dimethylphenyl)isophthalamide (17). To a solution of $16(0.269 \mathrm{~g}, 1 \mathrm{mmol}), 2,6$-dimethylaniline $(0.12$ $\mathrm{ml}, 1 \mathrm{mmol})$, and TEA $(0.14 \mathrm{ml}, 1 \mathrm{mmol})$ in NMP ( $2 \mathrm{ml})$ was added the activating agent 1 $(0.422 \mathrm{~g}, 1.1 \mathrm{mmol})$. The mixture was stirred at room temperature until $\mathbf{1}$ was dissolved completely in NMP, and then at $80^{\circ} \mathrm{C}$ for $15 \mathrm{~h}$. The product was isolated as described above. The yield was $0.340 \mathrm{~g}(94 \%)$. Recrystallization from methanol-water afforded white plates. $\mathrm{mp} 252-254^{\circ} \mathrm{C}$. IR (KBr) v $3240(\mathrm{~N}-\mathrm{H})$,
$1640 \mathrm{~cm} \quad(\mathrm{C}=\mathrm{O}) .{ }^{13} \mathrm{C}$ NMR $\left(\mathrm{CF}_{3} \mathrm{COOD}\right)$ : 172.3, $171.4(\mathrm{C}=\mathrm{O}), 21.4,18.4\left(\mathrm{CH}_{3}\right), 141.6$, $141.5,137.5,136.1,134.5,134.1,133.7,133.4$, $133.1,131.7,131.0,130.7,130.3,128.8 \mathrm{ppm}$ $\left(\mathrm{C}_{\text {arom }}\right)$. Anal. Calcd for $\mathrm{C}_{24} \mathrm{H}_{24} \mathrm{~N}_{2} \mathrm{O}_{2}: \mathrm{C}$, $77.39 \%$; $\mathrm{H}, 6.49 \%$; N, 7.52\%. Found: $\mathrm{C}$, $77.42 \% ; \mathrm{H}, 6.51 \%$; N, $7.45 \%$.

\section{RESULTS AND DISCUSSION}

\section{Model Reaction}

Suter et $a l .{ }^{6}$ studied the polycondensation of terephthaloyl chloride with 2,6-disubstituted diamines by Schotten-Baumann procedure, and found ordered polymers $(s \simeq 0)$ were obtained by very slow addition of terephthaloyl chloride to the diamine. Therefore, we chose isophthalic acid (2b) and 2,6-dimethyl-pphenylenediamine (4) as a symmetric monomer and a nonsymmetric monomer, respectively. In the previous paper, ${ }^{11}$ we showed diphenyl(2,3dihydro-2-thioxo-3-benzoxazolyl)phosphate (1) was the new activating agent for the synthesis of amides and polyamides. It is a generally accepted principle that reactivity of a species varies inversely with selectivity. The activating agent 1 reacts with carboxylic acid to form an active intermediate, mixed carboxylic-phosphonic anhydride [RCOO$\left.\mathrm{PO}(\mathrm{O}-\mathrm{Ar})_{2}\right]$, the reactivity of which toward nucleophiles is lower than that of acid chlorides. Thus, a selective amidation was expected. By using this activating agent $\mathbf{1}$, the following model compound work was performed.

The kinetic parameters of interest are the ratio of rate constants for the reactions of functional groups of nonsymmetric monomer $\mathrm{XabX}, r=k_{\mathrm{bx}} / k_{\mathrm{ax}}$. The overall second order rate constants for the reaction of benzoic acid (2a) with substituted anilines in NMP in the presence of 1 were determined, where the aminolysis of the active intermediate is an important, probably rate-determining ștep. The results are shown in Table I (eq 1). 


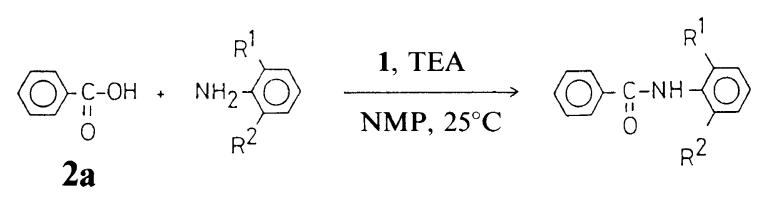

Table I. Overall second order rate constants for the reaction of $\mathbf{2 a}$ with substituted anilines in NMP at $25^{\circ} \mathrm{C}$ in the presence of $\mathbf{1}^{\mathrm{a}}$

Substituted aniline

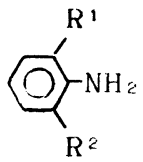

$\mathrm{R}^{1} \quad \mathrm{R}^{2}$

\begin{tabular}{lll}
\hline $\mathrm{H}$ & $\mathrm{H}$ & 1.12 \\
$\mathrm{CH}_{3}$ & $\mathrm{H}$ & 0.307 \\
$\mathrm{CH}_{3}$ & $\mathrm{CH}_{3}$ & 0.0119
\end{tabular}

a Reaction was carried out with $1 \mathrm{mmol}$ of each reactant at $25^{\circ} \mathrm{C}$ in the presence of $1(1 \mathrm{mmol})$.

The rate constants changed almost $10^{2}$ times when substituted anilines were varied from aniline to 2,6-dimethylaniline (3). This difference of reactivity toward to the active intermediate between aniline and $\mathbf{3}$ is enough to prepare a head-to-head or tail-to-tail polyamide.

Prior to the synthesis of sequential polyamides, the following model compound work was performed by the direct procedure to determine if the model compounds were formed in quantitative yields to constitute a polymer-forming reaction. This procedure consists of adding 1 to a solution of carboxylic acid and amine in NMP that contain a tertiary organic base to form a carboxylate anion.

The reactions of diamine 4 with $2 \mathbf{a}$ and that of $\mathbf{2 b}$ with $\mathbf{3}$ or 3,5-dimethylaniline were studied (eq 2).
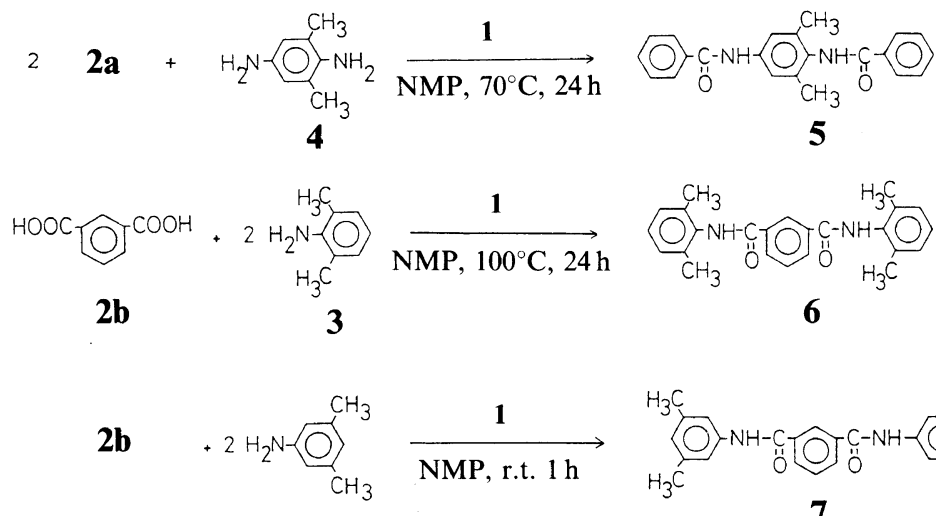

These reactions afforded the model compounds, $N, N^{\prime}$-dibenzoyl-2,6-dimethyl- $p$ phenylenediamine (5), $N, N$-di( $\left(2^{\prime}, 6^{\prime}\right.$-dimethylphenyl)isophthalamide (6), and $N, N^{\prime}-\operatorname{di}\left(3^{\prime}, 5^{\prime}-\right.$ dimethyl)isophthalamide (7) in quantitative yield. However, a low reactivity of 2,6-dimethylaniline moiety required high temperature and long reaction time for the completion of the reaction.

\section{Polymer Synthesis}

Synthesis of Authentic Polyamide

The authentic polyamides, such as head-tohead or tail-to-tail, head-to-tail, and random polyamides were synthesized for characterization of the structure of sequential polyamides 
obtained by the direct polycondensation.

The authentic head-to-head or tail-to-tail polyamide (9) was prepared by the direct polycondensation of $\mathbf{2} \mathbf{b}$ with $N, N^{\prime}$-di(4'-amino$3^{\prime}, 5^{\prime}$-dimethylphenyl)isophthalamide (8) which was obtained from $\mathbf{2 b}$ and 4 (eq 3 ).

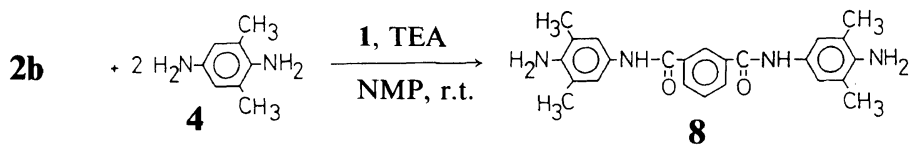

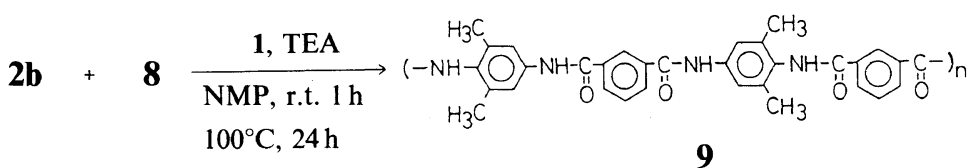

The polycondensation proceeded smoothly and gave the polyamide 9 with inherent viscosity of $0.26 \mathrm{dl} \mathrm{g}^{-1}$.
The authentic head-to-tail polyamide (12) was prepared as shown in eq 4 .

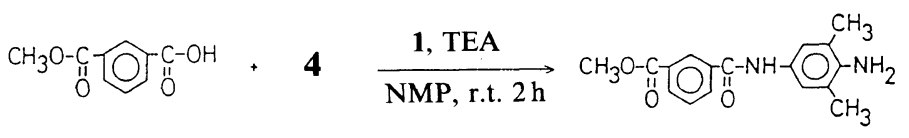

$$
\begin{aligned}
& 10 \\
& 10 \stackrel{\text { i) } \mathrm{KOH}}{\text { ii) } \mathrm{H}^{+}} \\
& \text {ONO-C }
\end{aligned}
$$

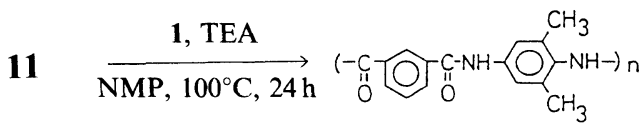

The condensation of methyl hydrogen isophthalate with 4 in the presence of 1 gave 4'-amino-3-methoxycarbonyl-3', 5'-dimethylbenzanilide (10), which was treated with alkaline solution to afford 4'-amino-3-carboxy3',5'-dimethylbenzanilide (11). The direct selfpolycondensation of monomer 11 was carried out with the activating agent 1 in NMP at $100^{\circ} \mathrm{C}$, and produced polyamide 12 in quantitative yield with inherent viscosity of $0.37 \mathrm{dl} \mathrm{g}^{-1}$.

Finally, the random polyamide (13) was synthesized from isophthaloyl chloride and $\mathbf{4}$ by mixing both monomers at once (eq 5 ).

$$
\stackrel{\mathrm{Cl}-\mathrm{C}}{\mathrm{O}} \widehat{\mathrm{O}} \mathrm{O}_{\mathrm{O}}^{\mathrm{C}-\mathrm{Cl}}+\mathrm{4} \longrightarrow \text { random polyamide } 13
$$

Synthesis of Sequential Polyamide (head-tohead, or tail-to-tail)

As briefly described at introduction, if $\mathrm{XabX}$ monomer is mixed all at once with $\mathrm{YccY}$ monomer, only random polymer can be obtained. To obtain the head-to-head or tail-to-tail polymer, YccY should be added slowly to XabX, that is, if YccY is added slowly to $\mathrm{XabX}$ so that there will never be any unreacted $-\mathrm{cY}$ groups. After half of the YccY is added, the only $\mathrm{XbaccabX}$ will be produced. Upon addition of the rest of YccY, only - bccb- 
structures will be formed. Accordingly, the resulting polymer will contain-acca- and -bccb-arrangements only, and $s=0$.

The synthesis of the sequential polyamide was performed by slow addition of symmetric monomer $2 \mathrm{~b}$ to nonsymmetric monomer 4 . The polycondensation proceeded smoothly and gave polyamide 14 with inherent viscosity of $0.2 \mathrm{dlg}^{-1}$ (eq 6).

$$
2 \mathrm{~b}+\mathbf{4} \underset{\mathrm{NMP}, 100^{\circ} \mathrm{C}, 24 \mathrm{~h}}{\stackrel{1}{\mathrm{~T}} \mathrm{TEA}} \text { polyamide } 14
$$

\section{Polymer Characterization}

The IR spectra of the polyamides were consistent with model compounds and known analogues. All polyamides prepared showed characteristic $\mathrm{N}-\mathrm{H}$, amide I and amide II bands in the range $3220-3320,1630-1640$, and $1520-1540 \mathrm{~cm}^{-1}$, respectively. Elemental analyses also supported the formation of the expected polymers.

The most conclusive spectra evidence for the proposed polyamide structures and especially for the sequential polyamidation, was provided by ${ }^{13} \mathrm{C} \mathrm{NMR}$. The ${ }^{13} \mathrm{C}$ chemical shifts (in $\mathrm{CF}_{3} \mathrm{COOD}$ ) of amide carbonyl groups for model compounds are shown in Scheme 1 in order to clarify the structure of polymer (Scheme 1).
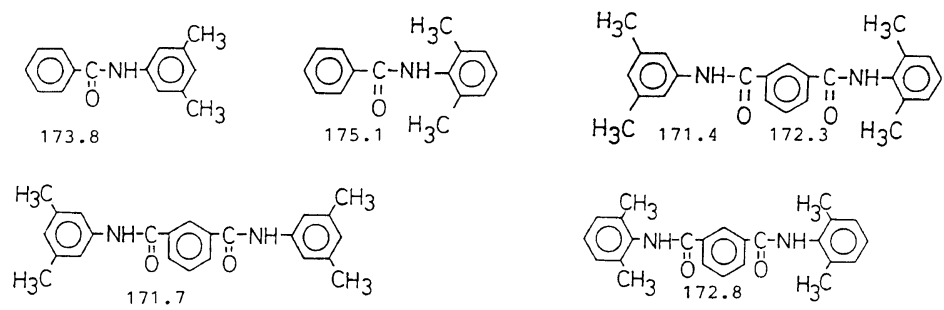

Scheme 1.

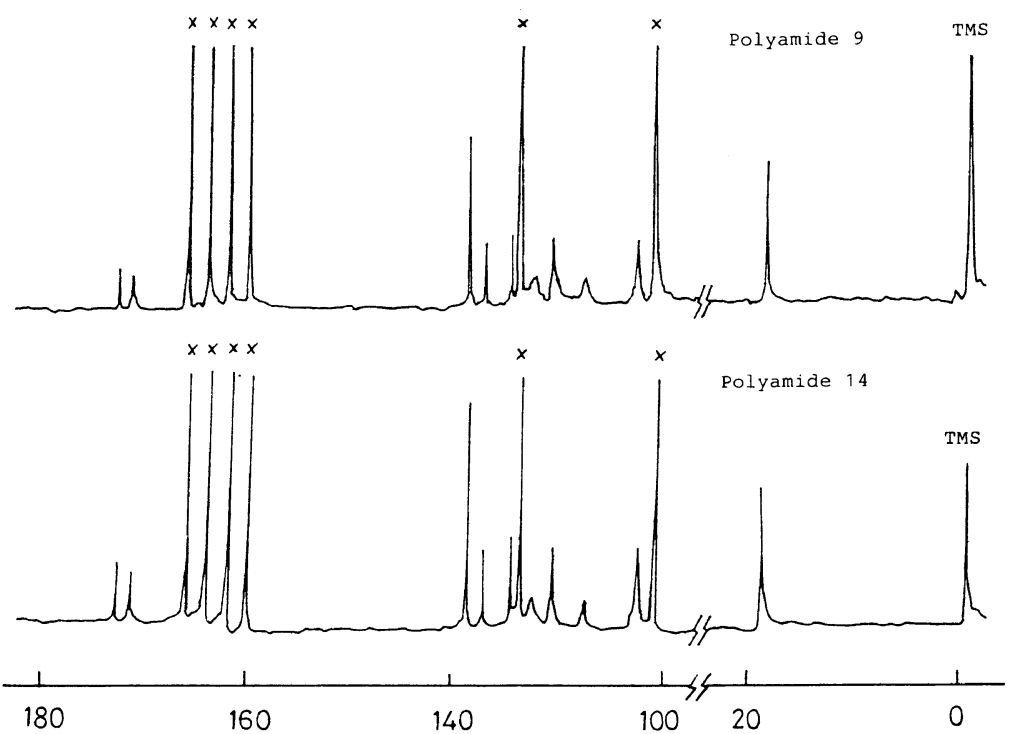

Figure 2. ${ }^{13} \mathrm{C}$ NMR spectra of authentic polyamide 9 and polyamide 14 in $\mathrm{CF}_{3} \mathrm{COOD}$ at $25^{\circ} \mathrm{C}$. $(\times)$ $\mathrm{CF}_{3} \mathrm{COOD}$ used as a solvent. 
The ${ }^{13} \mathrm{C}$ NMR spectra of polyamide 14 and authentic polyamide 9 are presented in Figure 2. The spectrum of polyamide $\mathbf{1 4}$ is identical to that of polyamide 9 . The ${ }^{13} \mathrm{C}$ chemical shifts of amide bond for authentic polyamide $\mathbf{9 , 1 2}$ are shown in Scheme 2.

Polyamide (head-to-head/tail-to-tail) 9

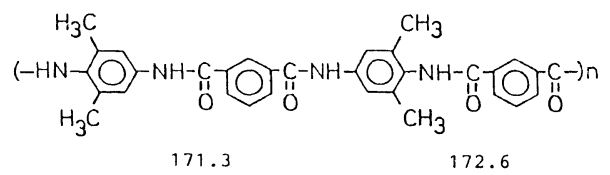

Polyamide (head-to-tail) 12

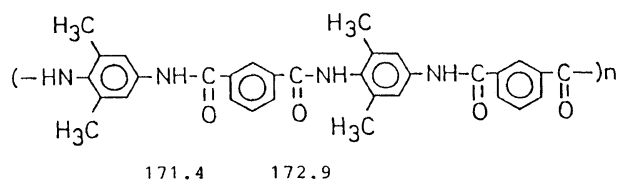

Scheme 2.

The resonances with $\mathrm{CO}$ chemical shifts in the amides between 171 and $173 \mathrm{ppm}$, are assigned, as shown in the inset in Scheme 2, on the basis of assignments for model compounds.

On the other hand, the peaks of carbon nuclei in amide carbonyl groups for polyamide 13 were observed at 171.2, 172.5, and $172.7 \mathrm{ppm}$ (Figure 3). However, four peaks would be expected to appear for polyamide 13 . It can be assumed that the difference in the chemical shifts at around $171 \mathrm{ppm}$ is so small that two peaks are overlaped.

These findings clearly indicate that the direct polycondensation of $\mathbf{2 b}$ and $\mathbf{4}$ produced the desired head-to-head, or tail-to-tail $(s \simeq 0)$ polyamide.

The polyamides obtained were white, soluble in sulfuric acid, methanesulfonic acid, and dipolar aprotic solvents. The constitutional regularity would be expected to give the different properties of polyamides. However, there was no much difference in the solubility among these polyamides, only polyamide $\mathbf{1 3}$ was readily soluble in pyridine, but other polyamides, $9,12,14$ were partially soluble.

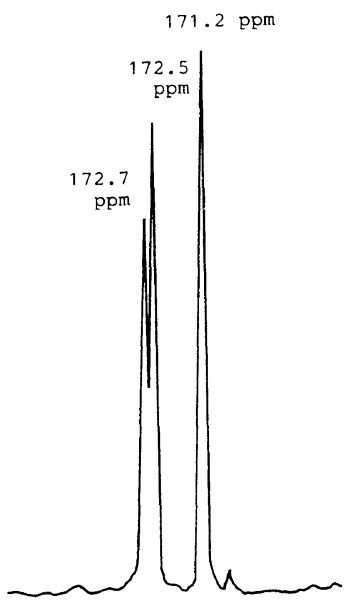

Figure 3. ${ }^{13} \mathrm{C}$ NMR spectrum of amide carbonyl group of polyamide 13 in $\mathrm{CF}_{3} \mathrm{COOD}$ at $25^{\circ} \mathrm{C}$.

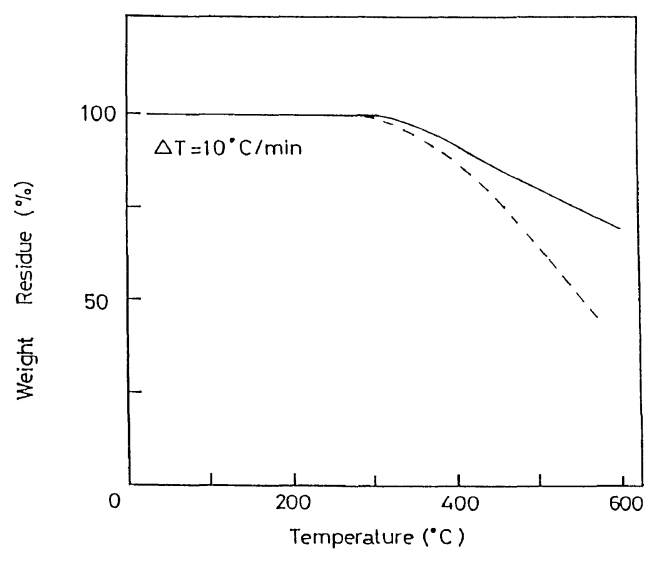

Figure 4. TG curves of polyamide 14 in nitrogen (-) and in air (---).

Thermal stability of the polymers was examined by thermogravimetry (TG). The samples were dried in vacuo at $150^{\circ} \mathrm{C}$ for $2 \mathrm{~h}$, and subsequently subjected to $\mathrm{TG}$, with representative curves shown in Figure 4. The polyamides showed a $10 \%$ weight loss at $415-420^{\circ} \mathrm{C}$ in nitrogen, and no difference in their thermal stabilities owing to different regularity can be detected. The similar behavior was observed for studies of the influence of constitutional isomerism on the physical properties of polycondensate, and Pino et al. reported that unsubstituted polyamides might 
not be very suitable because strong effects brought about by extensive interchain ¿NH $\cdots$ OC - bonds might mask subtle effects due to isomerism. ${ }^{10}$

In summary, we have demonstrated that the synthesis of sequential polyamide (head-tohead, or tail-to-tail) can be achieved by the direct polycondensation of symmetric monomer with non-symmetric monomer using the activating agent $\mathbf{1}$. The polycondensation was carried out by slow addition of a solution of 2b, 1 and TEA in NMP to a solution of 4 in NMP.

Acknowledgments. The authors are indebted to Mr. Sadao Kato for his technical assistance and to Mr. Takeyoshi Takahashi for performing the elemental analyses. This work was partly supported by a Grant-in-Aid for Scientific Research (No. 01550706) from the Ministry of Education, Science, and Culture of Japan.

\section{REFERENCES}

1. a) F. Higashi, Yuki Gousei Kagaku Kyokaishi, 40, 922
(1982); b) F. Higashi, ibid., 47, 994 (1989); c) Y. Imai, Sen'i Gakkaishi, 40, 137 (1984); d) M. Ueda, Kobunshi, 35, 128 (1986); e) M. Ueda, Yuki Gousei Kagaku Kyokaishi, 48, 144 (1990).

2. M. Ueda, T. Morosumi, M. Kakuta, and R. Sato, Polym. J., 22, 733 (1990).

3. Pino, G. P. Lorenzi, U. W. Suter, P. G. Casartelli, A. Steinmann, F. J. Bonner, and J. A. Quiroga, Macromolecules, 11, 624 (1978).

4. U. W. Suter and P. Pino, Macromolecules, 17, 2248 (1984).

5. M. A. Schmucki, P. Pino, and U. W. Suter, Macromolecules, 18, 823 (1985).

6. W. R. Meyer, F. N. Gentle, J. E. Garo, and U. W. Suter, Polym. Prepr., Am. Chem. Soc., Div. Polym. Chem., 27 (2), 223 (1986).

7. F. T. Gentile, W. R. Meyer, and U. W. Suter, Polym. Prepr., Am. Chem. Soc., Div. Polym. Chem., 28 (2), 288 (1987).

8. W. R. Meyer, F. N. Gentle, and U. W. Suter, Polym. Prepr., Am. Chem. Soc., Div. Polym. Chem., 28 (2), 290 (1987).

9. F. T. Gentle and U. W. Suter, "Comprehensive Polymer Science," Vol. 5, G. Allens and J. C. Bevington, Ed., Pergamon Press, Oxford, 1989, p. 97.

10. G. Xie, P. Pino, and G. P. Lorenzi, Macromolecules, 23, 2583 (1990).

11. M. Ueda, A. Kameyama, and K. Hashimoto, Macromolecules, 21, 19 (1988).

12. E. Noelting and G. Thesmar, Ber. Deutsch. Chem. Ges., 35, 647 (1902). 